\section{Hydrogen Sulphide Gas as a Preventive of Putrefaction}

Is a collection of old microscope slides recently re-examined, a series came to light illustrative of observations made by me some twelve years ago and not hitherto published. They are perhaps of sufficient interest to be put on record now.

During the course of work on the sterilization of dried hides from anthrax ${ }^{1}$, the lines of which were suggested by observations by Andrjewski ${ }^{2}$, on the toxicity of hydrogen sulphide for anthrax spores, it was found that anthrax spores could be killed by exposure in anærobic jars to an atmosphere of this gas.

To find out whether hydrogen sulphide was toxic in the same conditions to other micro-organisms and might therefore delay or prevent putrefactive changes, the following experiment was done. Pieces of raw hide newly removed from the animal were put in anærobic jars---either suspended or laid in petri dishes. The air in the jars was then exhausted by means of a vacuum pump and hydrogen sulphide run in from a kip--being passed first over 1 per cent caustic soda to remove any trace of hydrochloric acid that might be present. The jars were allowed to stand at room temperature or at $37^{\circ} \mathrm{C}$. Cuttings from the samples under treatment were taken at intervals, sectioned, stained and compared with cuttings from the same hide kept in air in similar jars at the same temperatures. The hydrogen sulphide jars were refilled at once with the gas after each time of opening.

It was found that in the pieces kept in an atmosphere of hydrogen sulphide, putrefaction was almost entirely checked for a period of at least a week at $37^{\circ} \mathrm{C}$. and a month at (approximately) $20^{\circ} \mathrm{C}$. One hydrogen sulphide jar was kept sealed (and forgotten) for eight years. At the end of that time the sample of hide was still moist and sufficiently intact to .be sectioned, and though the epidermis and cellular structures in general had disappeared and there was considerable breakdown of the fibre bundles, the main outlines of the hide structure were still traceable.

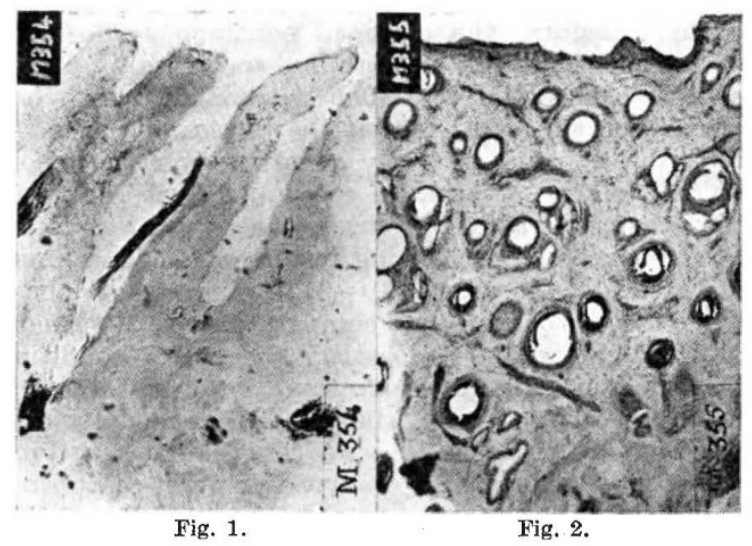

Fig. 1. OX HIDE KEPT FOR THREE DAYS IN AIR AT $37^{\circ} \mathrm{C}$. IN A SEALED JAR.

The epidermis and all the other cellular structures (sebaceous and sweat glands, linings of hair follicles and interstitial cells) have disappeared. The flbre bundles are loosely woven and are showing signs of breakdown.

Fig. 2. OX HIDE KEPT FOR SEVEN DAYS AT $37^{\circ} \mathrm{C}$. IN HYDROGEN SULPHIDE IN A BHALED JAR.

The epidermis and other cellular structures are intact or practically so. The flbre bundles are compactly woven and show little or no sign of degeneration.
The accompanying photomicrographs illustrate the condition of the air-treated sample after three days at $37^{\circ} \mathrm{C}$. and of that treated with hydrogen sulphide after seven days at the same temperature.

Unfortunately the section shown in Fig. 1 was cut in the direction of the hair follicles and that shown in Fig. 2 across their main direction. In spite of this, however, the much better state of preservation of the sample shown in Fig. 2 is obvious.

\section{British Leather Manufacturers'}

MADGE E. ROBERTSON.

Research Association,

1-6 Nelson Square,

London, S.E.1.

Feb. 13

${ }^{1}$ Robertson, J. Hyg., 32, 367 (1932).

${ }^{2}$ Andrjewski, Amer. J. Bact., 16, 151 (1928).

\section{Vernalization of Rice by Short Days}

IN a previous communication ${ }^{1}$, the effectiveness of the method of vernalization of rice by short days has been reported. The method has been tried further with several varieties of rice grown in Bengal, and interesting results of agricultural importance in one winter variety, 'Rupsail', have been noted.

Flowering duration of this variety has been reduced from 133 to 47 days by this method. So far as we are aware, flowering of winter varieties of rice within such a short period has not been reported previously. By applying short days to several varieties of rice, Alam $^{2}$ came to the conclusion that all varieties require a minimum period of 30 days for vegetative growth and a succeeding period of about 30 days of short-day treatment for coming into flower.

This acceleration of flowering has great possibilities for the cultivation of rice in Bengal. First, a variety of fine rice could be grown in a much shorter time; secondly, by inducing early maturity, it could escape flood; and thirdly, early harvesting would leave sufficient time for the preparation of fields for the crops following in rotation.

A full report of this work will be published elsewhere. We wish to express our thanks to Prof. S. P. Agharkar for encouragement and facilities to carry out this investigation.

S. M. Strcar.

Department of Botany,

B. Parija.

University of Calcutta. Nov. 7.

${ }^{1}$ Nature, 153, 378 (1944).

${ }^{2}$ See Sci. Rep. Rice Res. Stat., Sabour, Bihar (India), 1940-41.

\section{Two New Records of Sphacelia from Mysore}

E. IN the course of his studies on the sugary disease of Sorghum vulgare caused by Sphacelia Sorghi McRae, Ajrekar ${ }^{1}$ recorded three other wild grasses, namely, Andropogon caricosus var. molicomous, Ischcemum pilosum and Pennisetum alepecuros as having the Sphacelial stages of an ergot. Sclerotial stages were observed by him only on the last-named host, and he pointed out that heavy infestation by a species of Cerebella competed with the formation of sclerotial stages in other cases.

Collections of ergot on wild grasses in Mysore I have made included Sphacelial and sclerotial stages 